\title{
IMPLEMENTASI LEGISLASI BENIH DALAM MENSUKSESKAN SWASEMBADA PANGAN
}

\author{
Valeriana Darwis \\ Peneliti di Pusat Penelitian Sosial Ekonomi dan Kebijakan Pertanian \\ E-mail: valerianadrwis@yahoo.co.id
}

\begin{abstract}
Seed has an important role to increasing the productivity of food crops and has has a lot of legislation issued by the government relating to seed. However, to date there are no known legislation from local government (PEMDA) on seed (specific location). At the current stage, the existing local legislation on seed was based on the initial legislation from the central government especially Cultivation Act No. 12/1992 and Government Legislation No.44/1995. To date the most important institution based on the existing legislation on seed is BPSBTPH (Seed Control and Certification Services Agency for Food Crops and Horticulture). BPSBTPH has a function to control and be responsible in seed production, from procurement, distribution and trading activities. To optimize their role and function the BPSBTPH should: (1) develop policy for agricultural enterprises or farmers who have been used un-labelled seed; (2) participate in supervising new seed products from other agencies; (3) more focus on supervising duties and less pressure on achieving target in production that was set by local government.
\end{abstract}

\section{Keywords : Implementation and Legislation Seed}

\begin{abstract}
Abstrak : Benih mempunyai peranan yang strategis dalam meningkatkan produktivitas tanaman pangan dan sudah banyak legislasi yang dikeluarkan oleh pemerintah yang berhubungan dengan perbenihan. Dalam pelaksanaannya pemerintah daerah tidak pernah membuat peraturan perbenihan spesifik lokasi, yang ada hanya meneruskan kebijakan dari pusat khususnya Undang Undang Budidaya nomor 12 tahun 1992 dan Peraturan Pemerintah Nomor 44 tahun 1995 tentang pembenihan tanaman. Dalam implementasi legislasi benih institusi yang berperan sangat besar adalah BPSBTPH. Tugas lembaga ini selain melakukan pengawasan juga bertanggungjawab terhadap produksi benih, baik dari segi pengadaaan, penyaluran dan perdagangan. Agar tugasnya menjadi optimal maka disarankan BPSBTPH (1) mempunyai kebijakan bagi perusahaan atau petani yang tidak mempergunakan benih tidak bersertifikat, (2) ikut mengawasi benih yang dikeluarkan oleh lembaga lain, (3) lebih fokus pada tugas pengawasan benih dan tidak dibebani oleh target produksi yang ditetapkan oleh pemerintah daerah.
\end{abstract}

Kata Kunci : Implementasi dan Legislasi Benih

\section{PENDAHULUAN}

Legislasi merupakan faktor awal dalam mensukseskan kebijakan yang dijalankan oleh pemerintah. Menurut Suprahtomo (2012) posisi legislasi dalam kebijakan adalah mendukung, mengawal proses mengamankan hasil pemerintah dan pembangunan. Legislasi juga ada di perbenihan yang secara umum diarahkan untuk memberdayakan para pelaku usaha dalam industri benih agar mampu bersaing di dalam negeri maupun pasar internasional. Kemajuan industri perbenihan diharapkan dapat meningkatkan kinerja sektor pertanian karena benih/bibit merupakan input yang peranannya sangat signifikan dalam menentukan produktivitas usahatani. 
Peraturan perundangan - undangan perbenihan yang ada sampai saat ini, antara lain: (i) Keppres Nomor 27/1971 tentang Badan Benih Nasional (BBN); (ii) Peraturan Pemerintah Nomor 22 tahun 1971 tentang pendirian Perum Sang Hyang Seri; (iii) Surat Keputusan Menteri Pertanian Nomor 174 tahun 1971 tentang pembentukan Dinas Pengawasan dan Sertifikat Benih; (iv) Undang-Undang Nomor 12/1992, tentang Sistem Budidaya Tanaman; (v) Undang-Undang Nomor 29/2002, tentang Perlindungan Varietas Tanaman (PVT); (vi) Peraturan Pemerintah Nomor 44/1995, tentang Pembenihan Tanaman; (vii) PP 13/2004 tentang penggunaan varietas asal untuk pembuatan varietas turunan esensial; (viii) PP 14/2004 tentang syarat dan tatacara pengalihan pembuatan varietas turunan dan penggunaan yang dilindungi oleh pemerintah; (ix) Peraturan Menteri Pertanian Nomor 37/2006, tentang Pengujian, Penilaian, Pelepasan dan Penarikan Varietas; (x) Peraturan Menteri Pertanian Nomor 38/2006, tentang Pemasukan dan Pengeluaran Benih, dan (xi) Peraturan Menteri Pertanian Nomor 39/2006, tentang Produksi, Sertifikasi dan Peredaran Benih Bina (Nugraha, 2004; Hidayat, 2006; Sayaka, et al, 2006; Suyamto, 2011).

Dalam rangka revitalisasi perbenihan dan perbibitan, Kementerian Pertanian dalam lima tahun mendatang mencanangkan kegiatan sebagai berikut: (1) Menata kembali kelembagaan perbenihan/perbibitan nasional mulai dari tingkat pusat sampai daerah; (2) Melindungi, memelihara dan memanfaatkan sumberdaya genetik nasional untuk pengembangan varietas unggul lokal; (3) Memperkuat tenaga pemulia dan pengawas benih tanaman; (4) Memberdayakan penangkar dan produsen benih berbasis lokal; (5) Meningkatkan peran swasta dalam membangun industri perbenihan/perbibitan; (6) Membangun industri perbenihan dengan arah sebagai berikut: (i) Kemandirian industri benih nasional yang mencakup kemandirian produksi benih dan industri varietas; (ii) Kemandirian penyediaan benih berbasis kawasan; (iii) Industri benih berbasis komunitas; (iv) Riset berbasis perbenihan (Kementerian Pertanian, 2010a).

Peran benih unggul dan bermutu dalam peningkatan produktivitas sudah disadari oleh pemerintah sejak lama. Oleh karena benih menjadi salah satu faktor utama dalam meningkatkan produktivitas dan produktivitas juga mempengaruhi akan keberhasilan pemerintah dalam mewujudkan swasembada pangan. Dengan penjelasan tersebut maka tulisan ini bertujuan ingin melihat implementasi beberapa legislasi perbenihan, dampak penerapan kebijakan perbenihan serta permasalahan implementasi perbenihan.

\section{METODOLOGI}

Swasembada pangan terkait erat dengan dua sisi, yaitu sisi ketersedian/produksi dan sisi permintaan. Kajian ini difokuskan untuk mengkaji dari sisi ketersedian komoditas padi, jagung dan kedelai. Dari sisi ketersediaan, peningkatan produksi komoditas pertanian masih menjadi prioritas dalam pembangunan pertanian. Dalam rangka mendorong peningkatan produksi, pemerintah memberikan dukungan fasilitasi dengan peraturan perundangan-undangan. Implementasi peraturan perundangan-undangan dilakukan oleh kementerian / lembaga terkait dan pemerintah daerah, dalam bentuk program yang lebih operasional.

Penelitian dilakukan pada tahun 2012 dengan pemilihan lokasi berdasarkan : (i) Sentra produksi padi, jagung dan kedelai; dan (ii) Kedudukan/tempat institusi yang mengeluarkan dan terkait dengan implementasi peraturan perundangan benih dan pupuk. Berdasarkan kriteria tersebut maka provinsi yang terpilih adalah Jawa Barat dan di provinsi ini ada Balai Penelitian Padi (BB Padi), Provinsi Jawa Timur dan di provinsi ini ada Balai Penelitian Kacang-kacang dan Umbiumbian (Balitkabi), Provinsi Sulawesi Selatan dan di Provinsi ini ada Balai Penelitian Jagung.

Data dan informasi yang digunakan mencakup data dan informasi sekunder dan primer. Data primer dikumpulkan langsung dari responden, yakni seluruh pemangku kepentingan yang terkait dengan pelaksanaan legislasi sarana produksi yang mendukung swasembada pangan, serta kelompok sasaran penerima manfaat legislasi (kelompok tani). Data tersebut diperoleh melalui wawancara mendalam dalam diskusi kelompok. Wawancara mendalam (indepth interview) merupakan wawancara yang dilakukan secara intensif kepada informan, sehingga terelaborasi beberapa elemen dalam jawaban informan, 
yakni opini, nilai-nilai (values), motivasi, pengalaman-pengalaman maupun perasaan informan. Dalam wawancara mendalam, peneliti memperhatikan jawaban verbal maupun respon-respon non verbal dari informan. Cakupan data primer terdiri atas data kuantitatif (jawaban pertanyaan semi terstruktur dalam kuesioner) dan data kualitatif (data penjelas dari fenomena yang diamati) dari seluruh responden (Indraningsih et al. 2012).

Data sekunder diperoleh dari instansi, seperti Bappenas, Biro Hukum Sekretariat Jenderal Kementerian Pertanian, Direktorat Jenderal Tanaman Pangan, Direktorat Jenderal Prasarana dan Sarana Pertanian (Ditjen PSP), Dinas Pertanian Provinsi dan Kabupaten, Biro Hukum Bappeda Provinsi dan Kabupaten, Badan Pengawasan dan Sertifikasi Benih, Komisi Pengawas, dan serta instansi lain yang terkait. Data-data yang sudah terkumpul dianalisis dengan mempergunakan analisis deskriptif .

\section{HASIL DAN PEMBAHASAN}

Beberapa permasalahan yang terkait dengan kinerja sistem dan kelembagaan benih (Nurmanaf, et. al. 2003), antara lain: (i) struktur industri dan produksi benih di nilai tidak kondusif dalam menciptakan sistem usaha dan pasar yang sehat, (ii) konsekuensinya adalah tingkat harga yang tinggi sehingga tidak terjangkau oleh sebagian besar petani yang direfleksikan oleh tingkat partisipasi dan penggunaan benih berkualitas (berlabel) yang sangat rendah, (iii) efektivitas sistem distribusi yang lemah karena benih tidak selalu tersedia dipasaran saat petani membutuhkan, (iv) tidak tersedianya benih di lapangan karena resiko pemasaran yang tinggi sepenuhnya ditanggung oleh pengecer, (v) faktor eksternal yang ikut berpengaruh terhadap ketersediaan dan penggunaan benih, adalah masih relatif rendahnya tingkat efisiensi dan diversifikasi industri benih serta kinerja ekonomi perberasan yang kurang kondusif bagi pemanfaatan benih berkualitas.

Benih berkualitas yang dimaksud adalah benih bersertifikat. Dalam pertanian modern benih seringkali berperan sebagai delivery mechanism yang menyalurkan keunggulan teknologi kepada clients (petani dan konsumen lainnya) (Rachman et al. 2002). Sertifikat/label pada benih padi yang biasanya dikeluarkan oleh Balai Pengawasan dan Sertifikat Benih (BPSB) merupakan jaminan terhadap tingkat kualitas benih padi (Sarjana dan Rohman, 2012). Namun demikian, penggunaan benih padi bersertifikat di tingkat petani masih belum banyak digunakan. Secara keseluruhan jumlah petani padi yang menggunakan benih unggul bersertifikat hanya sekitar 30-40 persen dan sisanya merupakan benih sendiri yang dipilih dari hasil panen sebelumnya dan ditangani sama dengan cara penggunaan hasil untuk konsumsi (Rachman et al. 2002).

Berdasarkan sistem formal perbenihan nasional, varietas unggul yang baru dilepas (BS), yang dihasilkan oleh Puslitbang Komoditas diteruskan oleh Direktorat Benih untuk disebarkan ke BBI, yang selanjutnya diperbanyak untuk menghasilkan FS. Benih FS tersebut kemudian diperbanyak oleh BUMN (Perum SHS/PT Pertani), penangkar swasta, BBU dan BBP yang masing-masing memproduksi SS atau ES. Hal ini memungkinkan perlunya perhatian terhadap kelembagaan perbenihan jika ingin memperbaiki produktivitas padi di setiap sentra produksi, sebab kelembagaan yang kuat dapat menunjang pembangunan pertanian (Sudaryanto dan Pranadji, 2006, Suradisastra, 2006 dan Syahyuti, 2003).

\section{IMPLEMENTASI KEBIJAKAN PERBENIHAN}

Peraturan atau kebijakan tentang benih mengacu kepada Undang - Undang, kemudian ditindaklanjuti dalam bentuk Peraturan Pemerintah dan Keputusan Kementerian. Sementara pemerintah kabupaten atau kota tidak pernah membuat peraturan atau kebijakan tentang benih. Ada beberapa alasan kenapa hal ini bisa terjadi diantaranya adalah: (i) kebijakan benih umumnya dimasukan dalam kegiatan atau program yang dilaksanakan oleh pemerintah pusat seperti kegiatan SLPTT, CBN dan BLBU. (ii) Pemerintah daerah kurang begitu respon dengan benih terutama untuk padi, jagung dan kedele. (iii) Belum ada aturan main yang jelas mana yang menjadi tanggungjawab pusat dan tanggungjawab daerah dalam hal industri benih. 


\section{Implementasi Kebijakan Benih Tanaman Padi di Provinsi Jawa Barat}

Kebijakan perbenihan di Jawa Barat dilaksanakan oleh Balai Pengawasan dan Sertifikasi Benih Tanaman Pangan dan Hortikultura (BPSBTPH), sementara pelaksanaan kegiatan/program perbenihan dilaksanakan di Dinas Pertanian Provinsi Bandung. BPSBTPH belum membuat kebijakan benih tanaman pangan spesifik provinsi, yang ada sekarang masih meneruskan kebijakan yang sudah dikeluarkan oleh pemerintah pusat, terutama mengacu pada Undang-Undang Budidaya Nomor 12 dan Peraturan Pemerintah Nomor 44. Kedepannya ada kebijakan yang di inisiasi oleh Dinas Pertanian Provinsi dalam menseragamkan benih untuk Provinsi Jawa Barat dan kebijakan ini akan dikeluarkan akhir tahun 2012. Benih yang akan diseragamkan diminta oleh Provinsi Jawa Barat ke Balai Besar Padi (BB Padi). BB Padi mencari varietas berdasarkan galur murni yang cocok dengan kondisi Jawa Barat secara keseluruhan. Dari hasil kajian BB Padi ditemukan 3 jenis varietas yaitu : Pakuan, Parahyangan dan Pasundan. Sementara itu varietas yang menjadi ciri khas Jawa Barat dan diusahakan untuk dipatenkan adalah: varietas Pandan Wangi.

BPSBTPH Provinsi Jawa Barat dibentuk berdasarkan Peraturan Daerah Nomor 5 Tahun 2002 dan Keputusan Gubernur Jawa Barat Nomor 53 Tahun 2002, dengan tugas pokok dan fungsi di bidang pelayanan Pengawasan Mutu dan Sertifikasi Benih Tanaman Pangan dan Hortikultura serta Informasi Perbenihan Padi, Palawija dan Hortikultura. Selain itu lembaga ini mempunyai peranan yang sangat penting dalam fasilitasi penyediaan benih unggul bermutu guna mendukung peningkatan ketahanan pangan dan pengembangan agribisnis pertanian.

BPSBTPH berfungsi juga sebagai lembaga penilai calon produsen-pedagang benih dan penyalur-pedagang benih. Selain mengajukan permohonan dalam bentuk formulir, ada juga penilaiannya. Penilaian produsen-pedagang benih antara lain: (1) mempunyai pengetahuan cukup tentang cara menghasilkan benih bermutu; (2) mempunyai pengetahuan cukup tentang cara penyimpanan benih; (3) menguasai unit pengolahan benih untuk pengeringan, pembersihan, pengepakan; (4) menguasai atas gudang tempat penyimpan benih dan (5) jujur dan bersedia/selalu memenuhi peraturan perbenihan yang berlaku. Sementara untuk penyalur-pedagang benih yang dinilai adalah: (1) mempunyai pengetahuan cukup tentang cara menghasilkan benih bermutu; (2) menguasai atas tempat menjual benih dan (3) jujur dan bersedia/selalu memenuhi peraturan perbenihan yang berlaku.

\section{Implementasi Kebijakan Benih Tanaman Kedelai di Provinsi Jawa Timur}

Unit Pelaksana Teknis Pengawasan dan Sertifikasi Benih Tanaman Pangan dan Hortikultura (UPT PSBTPH) Provinsi Jawa Timur ditetapkan melalui Peraturan Daerah Nomor 31 Tahun 2000, yang diperbaharui dengan Perda Nomor 9 Tahun 2008 dan kemudian ditindaklanjuti dengan Keputusan Gubernur Jawa Timur Nomor 1 dan 16 tahun 2002, yang diperbaharui dengan Peraturan Gubernur Nomor 91 Tahun 2008 tentang Dinas Pertanian Provinsi Jawa Timur dan ditindak lanjuti dengan Peraturan Gubernur Jawa Timur Nomor 128 Tahun 2008 tentang Organisasi dan Tata Kerja.

Berdasarkan peraturan Gubernur Jawa Timur Nomor 128 tahun 2008, tentang Organisasi dan Tata Kerja Unit Pelaksana Teknis Dinas Pertanian Provinsi Jawa Timur. UPT Pengawasan dan Sertifikasi Benih Tanaman Pangan dan Hortikultura Provinsi Jawa Timur merupakan salah satu UPT yang bertugas melaksanakan sebagian tugas Dinas di bidang kultivar dan sertifikasi benih, pengujian benih secara laboratorium, pengawasan peredaran, ketatausahaan dan pelayanan masyarakat.

Kebijakan perbenihan yang dilaksanakan di Provinsi Jawa Timur merupakan lanjutan kebijakan yang sudah diterapkan oleh pemerintah pusat. Kebijakan khusus yang dikeluarkan untuk spesifik lokasi adalah Keputusan Gubernur Nomor 154 tahun 1989 tentang Forum Perbenihan Provinsi Jawa Timur. Forum ini merupakan wahana koordinatif, konsultatif dan informatif antara instansi pemerintah selaku badan pembina dan pengawas usaha pertanian maupun swasta selaku badan yang bergerak dalam pengadaan, penyaluran / perdagangan benih, guna 
membahas dan menyelesaikan berbagai masalah yang timbul yang menyangkut bidang pengadaaan dan penyaluran benih maupun harga benih.

\section{Implementasi Kebijakan Benih Tanaman Jagung di Provinsi Sulawesi Selatan}

Balai Pengawasan dan Sertifikasi Benih Tanaman Pangan dan Hortikutura (BPSBTPH) Provinsi Sulawesi Selatan lokasinya berada di Kabupaten Maros. Institusi ini berdiri sesuai dengan Surat Keputusan Gubernur Sulawesi Selatan Nomor 265 Tahun 2001, tanggal 26 November 2001 tentang Pembentukan Organisasi dan Tata Kerja Balai Pengawasan dan Sertifikasi Benih, maka kedudukan BPSBTPH menjadi Unit Pelayanan Teknis (UPTD) pada Dinas Pertanian Tanaman Pangan.

Tugas pokok UPTD BPSBTPH adalah: Melaksanakan sebagian tugas teknis Dinas Pertanian Tanaman Pangan dan Hortikultura Provinsi Sulawesi Selatan, khususnya dibidang pengawasan mutu dan sertifikasi benih tanaman pangan dan hortikultura. Adapun fungsi lembaga ini adalah : (i) melaksanakan penilaian kultifar dan klon penetapan pohon induk tanaman hortikultura tahunan, perencanaan perbenihan dan sertifikasi benih. (ii) pengujian benih secara laboratorium, (iii) pengawasan mutu dan peredaran benih, (iv) pengembangan teknologi mutu benih dan (v) ketatausahaan balai/administrasi. Selain itu BPSBTPH juga ikut berperan dalam mendukung penyediaan benih melalui kegiatan pelayanan sertifikasi dan pengawasan mutu benih kepada produsen yang menyediakan benih untuk pelaksanaan kegiatan Peningkatan Produksi Beras Nasional (P2BN), Cadangan Benih Nasional (CBN), SLPTT serta Program Provinsi Over Stock beras 2 juta ton dan produksi jagung 1,5 juta ton. Secara khusus BPSBTPH Provinsi Sulawesi Selatan tidak mengeluarkan kebijakan khusus tentang perbenihan komoditi jagung. Kebijakan yang dijalankan sekarang merupakan kebijakan yang sudah ditetapkan oleh pusat.

Pelaksanaan Kebijakan Perbenihan di Tingkat Penangkar

\section{Penangkar Benih Padi di Kabupaten Subang}

Dalam menangkar benih langkah yang pertama dilakukan adalah melaporkan ke BPSB Kabupaten Subang, kemudian BPSB melanjutkan dengan kegiatan pemantauan. Pemantuan dimulai pada saat kegiatan pemilihan areal tanam, kemudian dilanjutkan pada pengawasan pertumbuhan benih pada saat padi berumur 15 hari, 30 hari, 60 hari dan 10 hari sebelum panen. Setelah panen benih tersebut dijemur, dikipas dan kemudian petugas mengambil beberapa benih padi untuk di uji dengan metodologi yang sudah baku. Setelah 20 hari sertifikat keluar dan penangkar harus mengeluarkan biaya label (labeling) per bungkus $(5 \mathrm{~kg})$. Untuk label biru dikenakan biaya Rp. 200 perbungkus dan label unggu Rp. 300 perbungkus.

Penangkar ini, pada awalnya merupakan penangkar binaan PT. Pertani dan sekarang mengusahakan benih secara berkelompok dengan nama kelompok taninya adalah K3. Tahun ini kelompok K3 menangkar varietas Situ Bagendit seluas 25 ha, Cidenok 0,5 ha dan Mekonga seluas 7,5 ha. Situ bagendit umumnya dipasarkan ke luar Pulau Jawa, karena varietas ini sangat cocok di lahan tadah hujan.

Secara keseluruhan benih yang dihasilkan per hektar rata-rata $80-90$ ton permusim. Benih tersebut dipasarkan ke PT. Pertani sebanyak 30 persen, 50 persen ke sesama penangkar lokal atau petani dan 20 persen ke kios tani. PT Pertani biasanya membayar 2 sampai 3 hari, penangkar atau petani umumnya membayar langsung dan ke kios pembayaran dengan cara barter dengan pupuk. Benih yang dijual rata-rata Rp. 6.000 per kilogramnya. Kemudian benih tersebut dijual berkisar Rp. 7.000 sampai Rp. 8.000 perkilogramnya.

\section{Penangkar Benih Kedelai di Kabupaten Pasuruan}

Salah satu penangkar lokal di Kabupaten Pasuruan umumnya mengusahakan benih kedele setiap tahun seluas 10 ha dan meningkat menjadi 25 ha apabila ada kegiatan atau proyek dari Dinas Pertanian setempat seperti kegiatan SLPTT Kedelai. Benih yang dihasilkan umumnya di beli oleh petani sekitarnya dan benih yang dihasilkan untuk proyek akan 
dipergunakan oleh petani yang masuk CPCL kegiatan. Dalam memproduksi benih satu hektar dibutuhkan benih $40 \mathrm{~kg}$, pupuk phonska $150 \mathrm{~kg}$ dan petroganik $500 \mathrm{~kg}$. Benih yang dihasilkan dalam satu hektar sebanyak 1,8 ton dan benih tersebut dijual seharga Rp.6.700 per $\mathrm{kg}$. Berdasarkan pengalaman penangkar benih yang disertifikat dengan yang tidak disertifikat sama saja mutunya, malah benih yang disertifikat apabila tidak ada proyek justru mengalami kerugian. Hal ini disebabkan untuk menjadi benih bersertifikat dibutuhkan waktu paling cepat 20 hari, sementara usia kadaluarsa benih tersebut berkisar 1 sampai 2 bulan. Selain itu benih yang bersertifikat dijual dengan harga Rp. 11.000 per $\mathrm{kg}$ sementara benih tidak bersertifikat hanya Rp. 7.000 per kgnya.

\section{Penangkar Benih Jagung di Kabupaten Maros}

Penangkar melakukan kerjasama dengan PT SHS dalam menangkar jagung hibrida. Bentuk kerjasamanya adalah PT SHS memberikan benih jagung varietas SHS ke penangkar dengan jumlah dalam satu hektar sebanyak 16 $\mathrm{kg}$ dan biaya pemeliharaan sampai panen sebanyak Rp. 5 juta. Setelah itu penangkar harus menjual seluruh produksinya ke PT SHS. Dalam satu hektar dapat dihasilkan benih sebanyak 2,5 ton dan dibeli oleh perusahaan seharga Rp. 10.000 perkilogram. Benih yang dihasilkan penangkar tidak boleh dijual ke orang lain, karena bisa diperkarakan. Dan selama proses penangkaran jagung tersebut diawasi oleh petugas BPSBTPH. Penangkar tidak mengetahui varietas apa yang ditangkarkan, proses sertifikasinya karena menjadi tugas dari perusahaan dan berapa harga jualnya.

Pengalaman menjadi penangkar sudah sejak tahun 1997 dan kondisi sekarang membina 3 kelompok di tiga desa dengan luasan 150 hektar. Dalam satu tahun jagung ditanam dilokasi ini sebanyak dua kali dan satu kali untuk tanaman padi. Dalam perkembangannya petani yang menanam jagung hibrida mengalami peningkatan setiap tahun. Hal ini disebabkan pendapatan bertani jagung lebih menguntungkan mempergunakan jagung hibrida dibandingkan jagung komposit. Perbedaan yang nyata terjadi pada hasil produksinya (Tabel 1)

Adapun input yang dipergunakan baik untuk jagung komposit dan hibrida dalam satu hektar adalah : pupuk Urea $300 \mathrm{~kg}$ (Rp. 1.900/kg), Npk Phonska 250 kg (Rp. 2.300/kg) dan pupuk organik $500 \mathrm{~kg}$ (Rp. 500/kg). Jagung hibrida dan komposit yang dihasilkan diperuntukan untuk pakan ternak. Kelompok tani juga melakukan pembelian ke anggota kelompok jagung pipilan seharga Rp. $2.100 / \mathrm{kg}$. Jagung tersebut kemudian diolah menjadi pakan ternak dengan biaya pengolahan $\mathrm{Rp}$. 200/kg. Kemudian pakan tersebut dijual ke peternak dengan harga Rp. $2.600 / \mathrm{kg}$.

\section{DAMPAK PENERAPAN KEBIJAKAN PERBENIHAN}

Benih yang digunakan petani di Indonesia berasal dari dua sistem perbenihan, yaitu: (i) perbenihan formal (sumber benih bersertifikat) dan (ii) perbenihan informal (sumber benih tidak bersertifkat). Adapun ciri-ciri dari sektor perbenihan formal (sumber benih bersertifikat): (i) produksi dan pemasaran terencana; (ii) penggunaan varietas dengan nama yang jelas dan berasal dari sumber yang diketahui; (iii) benih dipasarkan dalam kemasan teridentifikasi dengan informasi mutu yang jelas; (iv) terdapat mekanisme pengendalian mutu yang jelas, produksi; (v) pemasaran dilakukan oleh lembaga yang terlibat dalam sistem perbenihan secara berkelanjutan; (vi) karakteristik petani

Tabel 1. Usahatani Penangkaran Jagung

\begin{tabular}{lrr}
\hline \multicolumn{1}{c}{ Uraian } & Jagung Hibrida & Jagung Komposit \\
\hline Benih & $20 \mathrm{~kg}$ & $25 \mathrm{~kg}$ \\
Produksi (pipilan) & $9-10 \mathrm{ton}$ & $7-8$ ton \\
Harga jual & $2.100 / \mathrm{kg}$ & $2.100 / \mathrm{kg}$ \\
Biaya Produksi & 5.000 .000 & 5.000 .000 \\
\hline
\end{tabular}

Sumber : Data Primer Diolah, 2012 
(produsen dan pengguna benih)-nya, antara lain: berorientasi komersial, banyak di antara mereka memiliki land holding cukup luas (> 0,5 ha), preferensi dan akses terhadap VUB sangat tinggi, tingkat penggunaan benih bersertifikat cukup tinggi (umumnya penggunaan benih bersertifikat setiap musim sampai 3 musim sekali), biasa menjual gabah pada saat panen.

Sementara ciri-ciri sektor perbenihan informal (benih tidak bersertifikat): (i) benih yang digunakan adalah hasil panen sendiri atau barter dari petani lain; (ii) proses produksi dan pemasaran benih tidak memiliki ciri-ciri seperti sektor formal (perencanaan yang jelas, pengendalian mutu formal dll); (iii) karakteristik petaninya: tanam VUL (VU yang dilepas < th 2000), akses ke sumber informasi teknologi \& VUB rendah, menggunakan benih tidak bersertifikat (atau benih bersertifikat dengan seed replacement rate sangat rendah), banyak yang subsisten, biasa menyimpan gabah (tidak biasa menjual gabah saat panen), dan luas pengelolaan lahan kecil $(<0,5 \mathrm{ha})$.

Menurut Nugraha dkk. (2007) petani yang mempergunakan benih bersertifikat hanya $40 \%$ sementara sisa adalah petani yang mempergunakan benih tidak bersertifikat (non formal). Sebagai bandingannya petani di negara lain yang mempergunakan benih bersertifikat : India 13,5 persen, Pakistan 5 persen, Bangladesh 4 persen, Vietnam 8 persen, New Zealand cereals 30 persen, U.S.A gandum 10 persen 7. Sementara pemakaian benih berlabel di Indonesia rata-rata dalam satu tahun untuk tanaman padi 22,02 persen (Tabel 2), tanaman jagung 7,04 persen (Tabel.3) tanaman kedele 2,80 persen (Tabel 4).

Tabel 2. Perkembangan Luas Panen Padi Berdasarkan Penggunaan Benih

\begin{tabular}{lccccc}
\hline Tahun & $\begin{array}{c}\text { Luas Panen } \\
(\mathrm{Ha})\end{array}$ & \multicolumn{2}{c}{ Berlabel } & \multicolumn{2}{c}{ Tidak Berlabel } \\
& & ha & $(\%)$ & ha & $(\%)$ \\
\hline 1996 & 11550045 & 2232252 & 19,33 & 9317793 & 80,67 \\
1997 & 11126396 & 2562959 & 23,03 & 8563437 & 76,97 \\
1998 & 11716499 & 2445960 & 20,88 & 9270540 & 79,12 \\
1999 & 11963204 & 2356055 & 19,69 & 9607149 & 80,31 \\
2000 & 11793475 & 2250442 & 19,08 & 9543033 & 80,92 \\
2001 & 11499997 & 3069239 & 26,69 & 8430758 & 73,31 \\
2002 & 11521166 & 1945375 & 16,89 & 9575791 & 83,11 \\
2003 & 11488034 & 2490796 & 21,68 & 8997238 & 78,32 \\
2004 & 11922974 & 3058007 & 25,65 & 8864967 & 74,35 \\
2005 & 11818913 & 3214913 & 27,20 & 8604000 & 72,80 \\
Rataan & 11640070 & 2562600 & 22,02 & 9077471 & 77,98 \\
\hline
\end{tabular}

Sumber : Dirjen Bina Produksi Tanaman Pangan, Direktorat Perbenihan. 2007

Tabel 3. Perkembangan Luas Panen Jagung Berdasarkan Penggunaan Benih

\begin{tabular}{lccccc}
\hline Tahun & $\begin{array}{c}\text { Luas Panen } \\
(\mathrm{ha})\end{array}$ & ha & Berlabel & \multicolumn{2}{c}{ Tidak Berlabel } \\
& 3685459 & 349929 & 9,49 & 3335530 & 90,51 \\
\hline 1996 & 3301795 & 235649 & 7,14 & 3066146 & 92,86 \\
1997 & 3815919 & 264092 & 6,92 & 3551827 & 93,08 \\
1998 & 3456357 & 139366 & 4,03 & 3316991 & 95,97 \\
1999 & 3500318 & 163710 & 4,68 & 3336608 & 95,32 \\
2000 & 3285866 & 236292 & 7,19 & 3049574 & 92,81 \\
2001 & 3126833 & 74421 & 2,38 & 3052412 & 97,62 \\
2002 & 3355511 & 376707 & 11,23 & 2978805 & 88,77 \\
2003 & 3356914 & 334519 & 9,97 & 3022395 & 90,03 \\
2004 & 3597875 & 253811 & 7,05 & 3344064 & 92,95 \\
2005 & 3448285 & 242849 & 7,04 & 3205435 & 92,96 \\
Rataan & 3 & ha & & \\
\hline Sur
\end{tabular}

Sumber : Dirjen Bina Produksi Tanaman Pangan, Direktorat Perbenihan. 2007 
Menurut Nurasa.T dan B. Sayaka (2009) ada beberapa alasan mengapa petani mau mempergunakan benih bersertifat dan beberapa alasan kenapa petani tidak mau mempergunakan benih bersertifikat. Alasan yang mau mempergunakan benih bersertifikat antara lain : (i) produksinya lebih tinggi, (ii) pendapatannya lebih besar, (iii) frekuensi penggunaannya bisa 2 kail tanam dalam setahu. Sedangkan alasan petani tidak mau mempergunakan benih bersertifikat antara lain : (i) tidak ada jaminan produktivitasnya akan tinggi, (ii) mutunya tidak berbeda jauh dengan yang tidak bersertifikat, (iii) harganya lebih mahal dan (iv) petani kurang akses terhadap benih bersertifikat tersebut.

Pentingnya pemakaian benih berlabel dalam meningkatkan produktivitas beras menjadi perhatian khusus Dinas Pertanian Provinsi Jawa Barat. Oleh karena itu pemda setempat sudah membuat road map meningkatkan penggunaan benih unggul bersertifikat dengan rata-rata produktivitas perhektarnya 6,5 ton pada tahun $2011 ; 6,68$ ton pada tahun 2012 dan 6,83 ton pada tahun 2012 (Tabel 5). Produsen benih kedele di Jawa Timur dihasilkan oleh kebun sendiri, kebun milik pemerintah kabupaten/provinsi, PT Pertani, PT SHS dan Pihak Swasta. Secara total benih yang dihasilkan pada tahun 1996 sebanyak 1.088 ton meningkat menjadi 7.055 ton pada tahun 2011 (Tabel 6).

\section{Permasalahan Implementasi Perbenihan}

Dalam implementasi pelaksanaan peraturan di bidang benih di provinsi contoh masih ditemukan berbagai permasalahan (secara ringkas ditampilkan pada Lampiran 1).

Permasalahan ditemui di Jawa Barat, antara lain:

Tabel 4. Perkembangan Luas Panen Kedele Berdasarkan Penggunaan Benih

\begin{tabular}{l|ccccc}
\hline Tahun & $\begin{array}{c}\text { Luas Panen } \\
(\text { ha })\end{array}$ & \multicolumn{2}{c}{ Berlabel } & \multicolumn{2}{c}{ Tidak Berlabel } \\
\cline { 2 - 6 } & 1277736 & 15526 & 1,22 & 1262210 & 98,78 \\
\hline 1996 & 1118140 & 16373 & 1,46 & 1101767 & 98,54 \\
1997 & 1094262 & 17671 & 1,61 & 1076591 & 98,39 \\
1998 & 1151079 & 17810 & 1,55 & 1133269 & 98,45 \\
1999 & 824484 & 17676 & 2,14 & 806808 & 97,86 \\
2000 & 678848 & 24521 & 3,61 & 654327 & 96,39 \\
2001 & 544522 & 22233 & 4,08 & 522290 & 95,92 \\
2002 & 526796 & 37736 & 7,16 & 489060 & 92,84 \\
2003 & 565155 & 41615 & 7,36 & 523540 & 92,64 \\
2004 & 621335 & 24250 & 3,90 & 597085 & 96,10 \\
2005 & 840236 & 23541 & 2,80 & 816695 & 96,59 \\
\hline Rataan & &
\end{tabular}

Sumber : Dirjen Bina Produksi Tanaman Pangan, Direktorat Perbenihan. 2007

Tabel 5.Peningkatan Produktivitas Melalui Penggunaan Benih Bersertifikat di Jabar

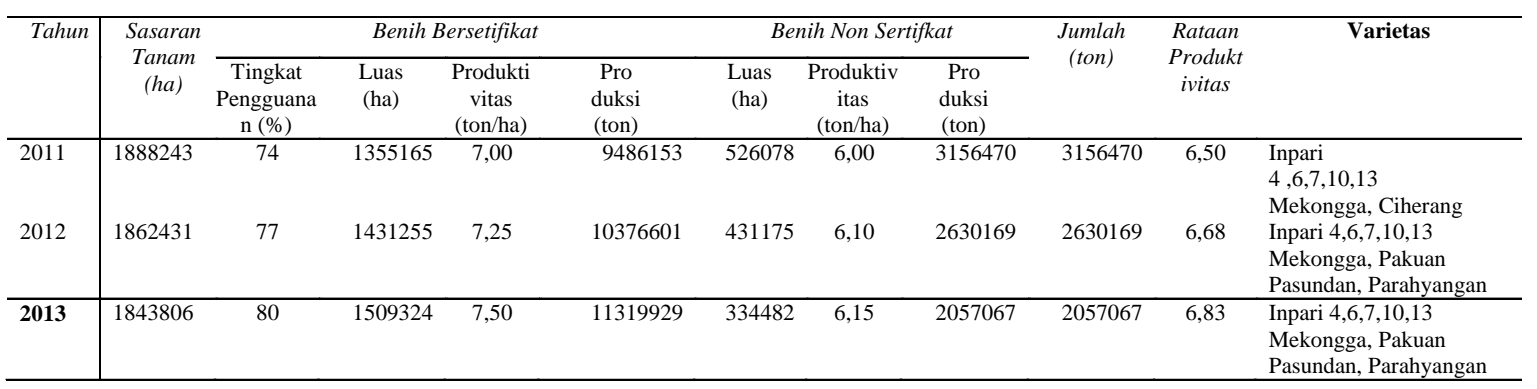

Sumber : Dinas Pertanian Provinsi Jawa Barat. 2012 
Valeriana Darwis : Implementasi Legislasi Benih dalam ....

Tabel 6. Perkembangan Produksi Benih Kedele di Jawa Timur 2011 menurut Produsen (ton)

\begin{tabular}{|c|c|c|c|c|c|c|}
\hline \multirow[t]{2}{*}{ Tahun } & \multicolumn{6}{|c|}{ Produsen } \\
\hline & $\begin{array}{c}\text { Kebun } \\
\text { Provinsi }\end{array}$ & $\begin{array}{c}\text { Kebun } \\
\text { Kab/Pusat }\end{array}$ & PT. Pertani & PT. SHS & Swasta & Jumlah \\
\hline 96/97 & 35 & - & 29 & 634 & 390 & 1.088 \\
\hline 97/98 & 32 & - & 8 & 371 & 36 & 448 \\
\hline 98/99 & 36 & - & 186 & 592 & 156 & 970 \\
\hline $99 / 00$ & 75 & - & 109 & 581 & 299 & 1.064 \\
\hline 2000 & 20 & - & 43 & 396 & 254 & 713 \\
\hline 2001 & 22 & - & - & 77 & 128 & 228 \\
\hline 2002 & 59 & - & - & 64 & 80 & 203 \\
\hline 2003 & 38 & - & - & 228 & 166 & 432 \\
\hline 2004 & 11 & 1 & - & 100 & 110 & 222 \\
\hline 2005 & 54 & 1 & 2 & 196 & 229 & 481 \\
\hline 2006 & 38 & 11 & - & 85 & 369 & 503 \\
\hline 2007 & 52 & 117 & 226 & 396 & 1770 & 2.562 \\
\hline 2008 & 65 & 502 & 518 & 1.516 & 2.795 & 5.396 \\
\hline 2009 & 104 & 675 & 233 & 541 & 4778 & 6.331 \\
\hline 2010 & 51 & 842 & 960 & 721 & 5.24 & 7.815 \\
\hline 2011 & 62 & 780 & 367 & 1.233 & 4.593 & 7.055 \\
\hline
\end{tabular}

Sumber : Laporan Tahunan UPT PSBTPH 2011

- Dalam pengembangan varietas, sebelum dikembangkan, varietas tersebut sudah melaui proses pelepasan varietas Tim Pelepasan Varietas Kemtan, tetapi dalam kenyataannya banyak varietas yang belum dilepas tetapi varietas tersebut sudah berkembang di masyarakat atau sudah diperjualbelikan. Kondisi ini disebabkan oleh banyaknya pemulia lokal atau petanipetani kreatif yang menangkarkan varietas. BPSBTPH tidak mempunyai aturan yang jelas untuk membina dan menindaklanjuti dalam mekanisme yang legal. Apabila ini dibiarkan tentu akan menyebabkan permasalahan terutama dalam masalah kualitas benih, hama penyakit, penurunan produktivitas, sejarah benih itu sendiri (kemurnian) serta petani tidak tahu mau meminta pertanggungjawabannya kepada siapa apabila mau komplain.

- Dalam prakteknya sertifikasi tidak hanya dilakukan oleh BPSBTPH, tetapi juga oleh produsen benih, contohnya PT SHS juga bisa melakukan sertifikasi. Walaupun benih berasal dari PT SHS, apabila ada permasalahannya, petani protesnya tetap ke BPSBTPH.

- BPSBTPH dibentuk berdasarkan Perda Nomor 5 Tahun 2002, Pergub Jabar Nomor 113 Tahun 2009 dan Nomor 50 Tahun 2010 serta Kepgub Jabar Nomor 22 Tahun 2003.
BPSB berada dibawah dan bertanggung jawab langsung kepada Kepala Dinas Pertanian Tanaman Pangan Provinsi Jawa Barat. Yang menjadi permasalahan sekarang adalah SDMnya semakin lama semakin berkurang dan kondisi sekarang tinggal 80 orang untuk seluruh provinsi.

- Dengan adanya otonomi daerah, maka struktur BPSBTPH juga mengalami perubahan. Sebelumnya struktur organisasi internal berdasarkan kelembagaan sekarang berdasarkan komoditi. Artinya satu orang menjalankan fungsi BPSBTPH mulai dari awal pemeriksaan areal tanam calon benih, pengawasan pertumbuhan vegetatif, generatif sampai pada saat mau panen serta pengambilan sample uji benih yang akan disertifikasi. Kondisi ini secara efisien sudah benar tetapi tidak efektif, hal ini disebabkan hasil pemeriksaannya tidak akan optimal karena dilakukan satu orang dan sangat lemah dalam fungsi kontrolnya.

- Sebaiknya kepala BPSBTPH adalah orang teknis, tujuannya agar terjadi masalah dilapangan akan lebih mudah mengeluarkan kebijakan aplikatif.

- BPSBTPH selain diberi tugas sebagai lembaga pengawas juga dibebani pengadaan benih. Kondisi ini bisa menyebabkan bias fungsi BPSB tersebut, hal ini terutama terjadi pada petugas benih tanaman (PBT). 
Tugas PBT yang seharusnya mengawasi mutu benih akan ragu-ragu menindak penangkar yang mutu benihnya jelek, apabila disandingkan dengan target waktu dan jumlah benih yang harus diadakan.

- PPNS tidak berjalan sebagaimana mestinya, hal ini karena tidak adanya petugas khusus yang menangani penyelidikan benih serta tidak tersedianya dana operasional.

Permasalahan ditemui di Jawa Timur, antara lain adalah:

- Peningkatan volume pelayanan pengawasan mutu dan sertifikasi benih setiap tahunnya cukup besar tetapi belum ada perimbangan dengan jumlah tenaga yang tersedia, khususnya Pengawas Benih Tanaman di setiap kabupaten/kota dan Satgas yang semakin tahun berkurang.

- Implementasi peraturan Menteri Pertanian Nomor 39 Tahun 2006 tentang produksi, sertifikasi dan peredaran benih bina, belum berjalan dengan baik terutama berkaitan dengan ijin produksi benih yang sudah menjadi kewenangan bupati/walikota.

- Ketentuan perundangan tentang tarif biaya jasa pemeriksaan lapangan dan pengujian sudah tidak sesuai dengan biaya operasional yang ada.

- Standarisasi peralatan laboratorium dan sarana prasarana mendesak untuk dapat dilaksanakan dalam rangka optimalisasi pelayanan dan jaminan mutu pengujian benih yang standar pada setiap laboratorium.

- Perlunya peningkatan mutu SDM pengawasan benih tanaman melalui pelatihan dan pendidikan dalam rangka kompetensi dan profesionalisme.

- Tugas pelayanan dalam rangka menindaklanjuti pengaduan masyarakat terhadap penggunaan dan peredaran benih non sertifikasi cukup besar, diperlukan upaya penanganan yang intensif oleh PPNS;

- Kebutuhan potensial benih kedele cukup banyak, tetapi ketersediaan benih sumber sangat terbatas, sehingga ditempuh langkah kebijakan untuk melakukan pemurnian varietas. Hambatan pemurnian varietas disebabkan karena calon benihnya banyak yang tidak terkuasai, produsen benih raguragu dalam penguasaan calon benih karena resikonya sangat besar, banyak calon benih tidak lulus campuran varietas lain, daya tumbuh dan kadar air. Untuk itu sangat diperlukan deregulasi peraturan perbenihan agar benih tersedia dalam jumlah yang cukup tetapi mutuh benih tetap dijaga dan dikawal sesuai dengan iklim dan tingkat permasalahan di daerah.

- Permasalahan utama dalam produksi benih kedele adalah penyediaan di musim penghujan, rata-rata benih yang dipanen pada bulan Januari-Febuari tidak lulus kadar air dan daya tumbuh. Dari uji coba hasil panen brangkasan dimusim hujan seringkali sudah tidak memenuhi standar daya tumbuh 80 persen sebelum benih diolah, disamping itu produsen juga membutuhkan dana yang sangat besar untuk penguasaan calon benih.

Permasalahan ditemui di Sulawesi Selatan antara lain adalah:

- Perlu peningkatan kualitas sumber daya manusia baik dalam menganalisis maupun pelaksanaan tugas pengawasan benih.

- Kurangnya petugas pengawasan benih dilapangan akibat pensiun atau mutasi ke pemerintah daerah kabupaten.

- Kurangnya dukungan sarana dan prasarana terutama dalam pengembangan metode maupun pelatihan pelayanan sertifikasi dilapangan dan pengujian benih di laboratorium.

- Belum seluruh areal penangkaran yang telah disertifikasi dapat diopkup menjadi benih sehingga diperlukan kemitraan/keterlibatan produsen swasta/ kelompok tani dalam hal penguasaan hasil penangkaran.

- Modal yang dimiliki oleh penangkar masih terbatas, mengakibatkan belum seluruh calon benih dapat diolah menjadi benih sehingga diperlukan penguatan modal terutama penangkar yang telah mampu memproduksi benih bermutu secara kontinyu dan profesional.

- Perencanaan kebutuhan benih bermutu dari varietas unggul belum disusun berdasarkan kebutuhan tiap musim tanam, sehingga belum sepenuhnya sesuai sasaran (jenis/varietas, jumlah, lokasi dan waktu).

- Fasiltas yang dimiliki oleh produsen swasta maupun kelompok tani masih terbatas, 
sehingga perkembangan kapasitas produksinya agak lambat.

- Alur perbanyakan benih yang telah ditetapkan belum optimal mendukung pengembangan sistem perbenihan. Sistem perbenihan perlu ditata sesuai alur perbanyakan disetiap wilayah.

- Penyediaan benih sumber (padi, jagung, kedelei) belum berkelanjutan, sesuai kebutuhan (jumlah, varietas dan waktu tanam) penangkar

\section{KESIMPULAN DAN SARAN}

\section{Kesimpulan}

Pemerintah Daerah tidak ada yang membuat legislasi khusus perbenihan tingkat provinsi atau kabupaten. Sampai sekarang pemda hanya meneruskan kebijakan perbenihan berdasarkan Undang-undang Budidaya nomor 12 tahun 1992 dan Peraturan Pemerintah Nomor 44 tahun 1995 tentang pembenihan tanaman.

Untuk meningkatkan produktivitas diperlukan benih yang bermutu dan benih yang bermutu harus melalui proses sertifikasi. Pentingnya sertifikasi juga dituangkan pemerintah dalam Peraturan Menteri Pertanian Nomor 39/2006 tentang Produksi, Sertifikasi dan Peredaran Benih Bina. Tetapi dalam prakteknya yang mempergunakan benih padi bersertifikat tidak sampai 50 persen, benih kedelai bersertifikat tidak sampai 10 persen

Lembaga yang melakukan sertifikasi di daerah adalah Balai Pengawasan dan Sertifikasi Benih Tanaman Pangan dan Hortikultura (BPSBTPH). Selain melakukan sertifikasi lembaga ini juga melakukan proses penilaian calon produsen, penyalur dan pedagang benih. Dengan tupoksi seperti ini maka tugas BPSBTPH sangat strategis, karena selain melakukan pengawasan juga bertanggungajawab dalam pengadaan benih di daerah.

Benih juga dapat diadakan oleh para penangkar dengan mengajukan permohonan menjadi penangkar ke BPSBTPH. Kemudian benih yang dihasilkan disertifikasi melalui pengajuan oleh penangkar itu sendiri atau melalui produsen benih ke BPSBTPH.

\section{Saran}

Agar perbenihan bisa lebih optimal dalam mewujudkan swasembada pangan, maka fungsi BPSBTPH ditingkatkan lagi khususnya dalam: (i) kebijakan pemberian sangsi kepada produsen benih yang memperjualbelikan benih sebelum dilakukan sertifikasi, (ii) lebih difokuskan kepada tugas pengawasan dan jangan lagi dibebani tugas target produksi, (iii) BPSBTPH juga diberi tugas ikut mengawasi benih yang dikeluarkan oleh lembaga lain yang sama-sama bisa mengeluarkan sertifikasi, (iv) masih dibutuhkan tenaga untuk mengganti tenaga yang pensiun dan meningkatkan keahlian tenaga yang ada.

\section{DAFTAR PUSTAKA}

Hidayat, J. R. 2006. Konsepsi Revitalisasi Sistem Perbenihan Tanaman. Iptek Tanaman Pangan Vol 1 No. 1. November 2006. P 163-181.

Indraningsih, K.I. 2012. Kajian Legislasi Penyuluhan Pertanian Mendukung Swasembada Pangan. Makalah disampaikan pada seminar proposal Operasional PSEKP 2012. Bogor 21-22 Februari 2012.

Kementerian Pertanian. 2010. Rencana Strategis Kementerian Pertanian Tahun 2010-2014. Jakarta.

Nugraha,S.U.2004. Legislasi, Kebijakan, dan Kelembagaan Pembangunan Perbenihan. Perkembangan Teknologi TRO VOL. XVI, No. 1 .

Nugraha, U.S., Sri Wahyuni, Aan A. Daradjat, Husin M. Toha, dan Ade Ruskandar. 2007. Model Pengembangan Sistem Perbenihan Untuk Akselerasi Diseminasi Varietas Unggul Baru: dengan penekanan pada Benih Padi. Draft Proposal, 2007. Balai Besar Penelitian Tanaman Padi, Sukamandi

Nurmanaf, A.R., I.W. Rusastra, V. Darwis, Y. Marisa dan J. Situmorang. 2003. Evaluasi Sistem Distribusi Benih dan Pupuk dalam Mendukung Ketersediaan dan Stabilitas Harga di Tingkat Petani. 
Pusat Penelitian Sosial Ekonomi Pertanian. Bogor.

Nurasa.T, dan B. Sayaka. 2009. Pengaruh Subsidi Benih Terhadap Produktivitas Padi di Jawa Timur. SOCA Vol 9 No 1. Fakultas Pertanian Universitas Udayana

Rachman,B., I.W. Rusastra dan K. Kariyasa. 2002. Sistem Pemasaran Benih dan Pupuk dan Pembiayaan Usahatani. Pusat Penelitian Sosial Ekonomi Pertanian.

Sarjana dan E. Rohman. 2012. Kinerja Pelaksanaan BLBU Dalam Mendukung Pengembangan Pengelolaan Tanaman Terpadu Padi Sawah di Kabupaten Grobogan. Prosiding Seminar Internasional Universitas Sebelas Maret.

Sayaka, B., K. Kariyasa, T. Nurasa, Waluyo, Y. Marisa. 2006. Analisis Sistem Perbenihan Komoditas Pangan Dan Perkebunan Utama. Pusat Analisis Sosial Ekonomi dan Kebijakan Pertanian.

Sudaryanto. T dan T. Pranadji. 2006. Transformasi Kelembagaan Untuk
Percepatan Adopsi Inovasi Teknologi Pertanian Pada Masyarakat Papua. Dalam J. Limbongan, M. Syukur, A. Malik, A.W. Rauf, M. Nggobe, Prosiding Seminar Nasional. Kerjasama BPTP Papua dan Pemda Provinsi Papua. 24-25 Juli 2006.

Suradisastra. K. 2006. Strategi Pemberdayaan Kelembagaan Petani. Forum Penelitian Agro Ekonomi. Vol 26 No. 2 Desember 2006.

Suprahtomo. 2012. Pembahasan Proposal Penelitian Kajian legislasi dalam Mendukung Swasembada Pangan. Makalah disampaikan pada seminar proposal Operasional PSEKP 2012. Bogor 21-22 Februari 2012.

Suyamto. 2011. Revitalisasi Sistem Perbenihan Tanaman Pangan. Iptek Tanaman Pangan Vol. 6 No. 1 -2011. p 1-13.

Syahyuti. 2003. Bedah Konsep Kelembagaan. Strategi Pengembangan dan Penerapannya dalam Penelitian Pertanian. Pusat Penelitian Sosial Ekonomi Pertanian. Bogor 


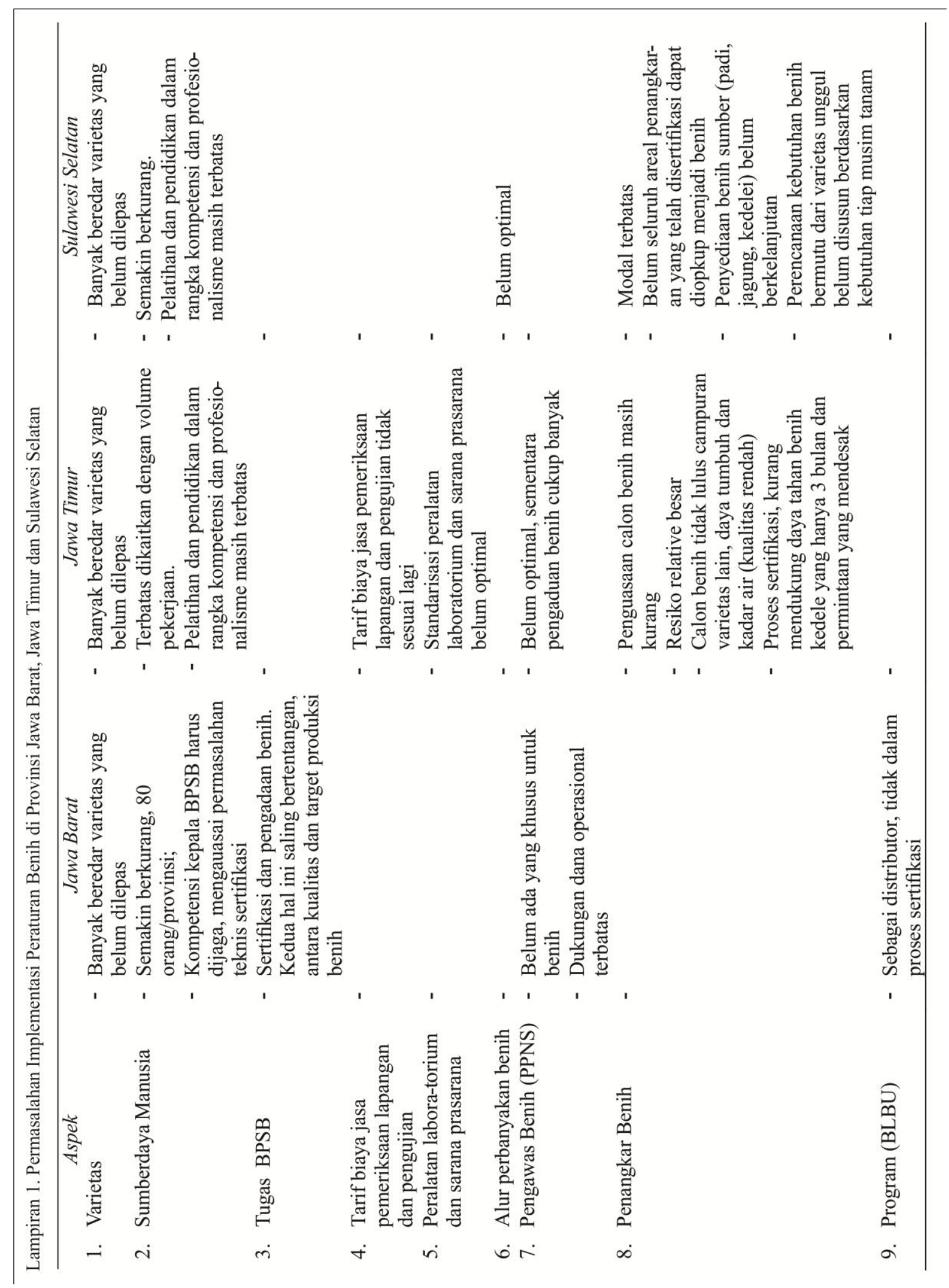

